\title{
Valentina Pisanty* \\ From the model reader to the limits of interpretation
}

DOI 10.1515/sem-2015-0014

Abstract: This paper discusses the role of the reader as developed by Umberto Eco in numerous instances: Lector in fabula (1979), I limiti dell'interpretazione (1990, The Limits of Interpretation), Interpretation and Overinterpretation (1992) and Dire quasi la stessa cosa (2003, Mouse or Rat? Translation as Negotiation). According to Eco, the interpretation of a text implies the grasping of the intentio operis by way of the intentio lectoris. Yet, the question to be asked is: what is the intentio operis and how can it be known? This is especially cogent since such intention is not explicit at the superficial level of the text but, rather, by way of various clues and suggestions that are disseminated throughout the text that the reader is actively involved in recognizing while eventually developing a specific interpretation of the text itself.

Keywords: Eco, interpretation, model reader, intentio operis, intentio lectoris, textual cooperation

\section{Text and interpretation}

In Umberto Eco's theory of semiotics, the notions of text and interpretation are closely interwoven: it is impossible to define one without referring to the other. On the one hand, it seems quite obvious that if there is interpretation, there must be something to interpret. This something is the text, which for Eco coincides with the Peircean sign ("something which stands for somebody for something in some respect or capacity," CP 2.228). On the other hand, Eco assumes that the interpretive possibilities of a text are to some extent embedded in the text itself. Consequently, the latter becomes a matrix of all possible readings: "a text is a product whose interpretive outcome must form part of its own generative mechanism" (Eco 1979a: 54). ${ }^{1}$

1 Original Italian: "un testo è un prodotto la cui sorte interpretativa deve far parte del proprio meccanismo generative." The book entitled Lector in fabula (1979a) has only been partially translated into English. Most of the main topics have been dealt with in The Role of the Reader

*Corresponding author: Valentina Pisanty, Università di Bergamo - Lettere, Filosofia, Comunicazione, Via Pignolo 123 Bergamo 24121, Italy, E-mail: valentina.pisanty@unibg.it 
The idea that every single interpretation of a text unfolds and develops one of the possible meanings already contained in embryo within the text itself also derives from Peirce, insofar as it is compatible with the idea of unlimited semiosis and with the centrality attributed by Peirce to the concept of interpretant in his definition of the sign. However, Peirce's cognitive semiotics focuses exclusively on what occurs on logical, cognitive, and semiosic levels when an interpretive process begins, while it has little to say on how a sign (or a text) is internally structured, and how its structure may impinge on the interpreter's activity. This is why Eco, who wants to bring the speculative level (i.e., the philosophical questions raised by a theory of General Semiotics) into interaction with the applicative level (textual analysis), turns to the other branch of semiotic studies, namely, Saussurian and Hjelmslevian semiology, to complete his definition of text. From this perspective, the text is seen as a discursive configuration whose "veins of meaning" may be probed at various structural levels. However, Eco differs from the most orthodox structuralists in that he considers these levels to be already loaded with interpretation even before the analyst brings them to light. This is why in The Role of the Reader he discusses "levels of possible abstraction at which the cooperative activity can take place" (1979b: 14-15; where cooperation involves the indivisible pair formed by the text and the interpreter).

Eco's model derives from a fruitful though problematic theoretical graft. By interpreting Peirce in the light of structuralism (and vice versa), Eco tries to combine two questions. The first question, inspired by Peirce, is "what happens when somebody interprets a text?" while the second, from a structuralist perspective, is "how is a text constructed (and how is the language that encodes it structured)?" The ensuing combined question is "what internal (structural) and external (communicative) factors allow the text to produce certain effects (rather than others) on its interpreters?"

This is basically the same question that has challenged biblical scholars, literary theorists, and hermeneutics experts, and also to a certain extent epistemologists and philosophers of science, for centuries. In his attempt to tackle such an age-old question, Eco proposes various definitions of what a text is, and how it interacts with its array of interpreters, be they real or virtual. In this paper I shall discuss some of the main stages through which Eco continued to develop his reflection on the interpretability of texts, moving back and forth between the two poles of semiotic theory (structure and interpretation), without ever renouncing one in favor of the other. At times he focused on the structuralist aspect of the

(1979b), especially in its introduction. However, it is not always possible to identify the exact conceptual correspondence between the Italian and the English texts. Most quotations in this article, in which I discuss the Italian book, have in fact been translated by me. 
question (i.e., the characteristics of the text and the interpreter's presence within it) while in other instances he took a more resolutely interpretive approach (as he concentrated on the cognitive processes that enable the reader to formulate his or her hypotheses on meaning). Not all questions raised by Eco's interpretive semiotics receive definite answers (this would be contrary to the principle of fallibility from which the theory is inspired). Many of the questions remain happily unanswered. In the following pages we shall examine some of them more closely.

We shall focus our attention particularly on how Eco negotiates his definition of the text/reader relationship. Sometimes he perceives the text as the root or source of all possible meanings, and at others he sees it as a system of restrictions that limit the spectrum of possible interpretations. The active role attributed to the reader in the generative process of meaning widens or narrows in inverse proportion to how widely or narrowly the text itself is conceived. The widest definition of the text as a matrix of all possible meanings thus implies a docile and cooperative interpreter who limits him or herself to following the textual instructions as from a script, while enhancing one or more possibilities of meaning that are already virtually embedded in the "lazy mechanism" of the text. Conversely, a narrower definition of the text as a mere system of restrictions holding back an otherwise unrestrained interpretive activity implies an adventurous and lively interpreter, whose wildest hypotheses come to a halt only when faced with the unquestionable evidence of contradiction with respect to what the text means or "wants to say" (how a text can "want" to say anything at all is one of the problems we shall deal with in the following pages).

The question about whether the above definitions ("text as a generative matrix" and "text as a system of restrictions") are mutually exclusive as alternative definitions of an ambiguous entity, or whether they can be synthesized into a single unified theory of the textual sign, is not something that this paper will be able to answer. Nevertheless, this problematic coexistence will provide a backdrop against which my argument will unfold. In order to proceed clearly, I shall begin by identifying the origins of the theory of interpretive cooperation, which is based on the idea that a text is (semantically) incomplete without the active involvement of an interpreter who fills the blanks that are necessarily present in the text itself.

\section{The open text}

The concept of "interpretive cooperation," which was extensively discussed by Eco in Lector in fabula (1979a), first appeared in Opera aperta (1962; partial English translation, The Open Work, 1989). In this collection of essays written between 1958 and 1962 Eco focused on a vast range of textual objects, such as 
aleatory music, Joyce's poetics, experimental literature, informal painting, Antonioni's cinema, and zen stories, all filtered through the mathematical theory of information, through which he developed the concept of the "openness" of a work of art. By and large, Eco defined what he intended as an "open work" in presemiotic terms. This is because his encounter with structuralism had yet to occur, as may be inferred by the 1967 preface to the second edition of his book. However, in the pages of Opera aperta we find the seeds of most of the concepts Eco was to develop in a semiotic vein in his later research.

The initial impulse was given by Eco's need to focus on the relationship between the work and the receiver (the "user") in the poetics of some avantgarde works. In a climate of lively artistic experimentation, Eco applied Luigi Pareyson's (1954) theory of formativity to "various instances when contemporary art has to reckon with Disorder" (Eco 1962: 2, my translation). ${ }^{2}$ By "disorder" he meant the level of entropy (or of informativeness) present in a message, with reference to the mathematical theory of information. The common factor between the different artistic representations investigated by Eco is their intentionally incomplete and ambiguous structure. Thus, the marked executive autonomy allowed to the interpreter by certain musical works (such as Luciano Berio's Sequence for Solo Flute), the indeterminateness of abstract and informal painting (e.g., tachisme and action painting), and the polivalence of the portmanteau words used by Joyce in Finnegan's Wake, are but some examples of works that require a certain effort by the user, an effort that is sometimes not only mental but also physical.

Pousseur has observed that the poetics of the "open" work tends to encourage "acts of conscious freedom" on the part of the performer and place him at the focal point of a network of limitless interrelations, among which he chooses to set up his own form without being influenced by an external necessity which definitively prescribes the organization of the work in hand. (Eco 1989b: 4) ${ }^{3}$

The concept of "open work" was therefore devised to account for the communicative functioning of a restricted category of artistic texts whose intentionally indefinite structure compels the users to take upon themselves the greater part of the production of meaning (if not of the material production of the text itself). On the basis of this definition, works are open if they "reject the definitive,

2 Original Italian: “[si propone] un'indagine di vari momenti in cui l'arte contemporanea si trova a fare i conti col Disordine." As is the case of the citations included below, this one from the "Introduction" of the 1962 Italian version of Open Work is not found in the English edition. 3 This citation derives from the chapter in The Open Work (1989b) entitled "The Poetics of the Open Work," which was rendered in English for the first time in The Role of the Reader (1979b: 47-66). 
concluded message and multiply the formal possibilities of the distribution of their elements" (Eco 1989b: 3), which the interpreter may follow. Eco's aim is to account for the particular aesthetic experience generated by such works, and to understand what, within the text itself, causes the user to be stimulated into becoming a co-author of the work.

Alongside this specific meaning of "openness," Eco immediately introduces another more extended meaning. He points out that even when a work is provided with a complete, canonical, fully-structured form, it is still open to a plurality of different interpretations depending on the reader's views, feelings, interests, prejudices, and so on. In fact, according to certain contemporary ideas of art at the time, the aesthetic value of a text depends on its ability to generate an indefinite number of different readings; "[the work of art] wants to be an inexhaustible source of experiences" (Eco 1989b: 24). Despite having a "closed" structure, a novel such as Alessandro Manzoni's I promessi sposi [The Betrothed 1840-1842] may be considered a work of art (therefore "open") inasmuch as it lends itself to a variety of possible interpretations. ${ }^{4}$ In such cases, the openness resides in the reader's "estranged" attitude towards the text, while being at the same time encouraged by the aesthetic text itself. ${ }^{5}$

1) A work of art, therefore, is a complete and closed form in its uniqueness as a balanced organic whole, while at the same time constituting an open product on account of its susceptibility to countless different interpretations which do not impinge on its unadulterable specificity. (Eco 1989b: 4)

Finally, in The Open Work we find a third meaning of "openness." In certain passages of the book, Eco suggests that, apart from those texts that display an aesthetic function, all other communicative devices lend themselves to a degree of openness, since they require the collaboration of interpreters who bring together the propositions they encounter with the sum total of the experiences they associate with the propositions themselves: "the halo of openness that radiates out of every proposition ... and that accompanies all human communication" (Eco 1989b: 30). Works of art are devices that make strategic use of the ambiguity and incompleteness inherent in every text, insofar as all texts are

4 This assertion can also be reversed: the text lends itself to various possible readings because it is considered a work of art (see, for example, Nanni 1987).

5 In his definition of this second meaning of the "openness" of a work of art, Eco refers to Pareyson's theory of formativity, as well as to the studies of Russian formalists, to Jakobson's study on the functions of language (1960) and to the positions of the nouvelle-critique (in particular to Barthes' Sur Racine). 
structured in such a way as to give their users some leeway for interpretative maneuvering, which may vary according to the type of text. ${ }^{6}$

By generalizing the problem of the open work to include the functioning of all communicative phenomena, Eco shaped the question that was to become a constant presence in his subsequent research: what stimulates and at the same time limits the activity of the interpreter in the text (aesthetic or otherwise)? In order to answer this question, Eco turns to semiotics. ${ }^{7}$

\section{Defining the text}

The word text did not form part of the terminology used by Eco in 1962 to describe the phenomenon of openness in a work of art, despite the frequent presence of terms such as work, message, and artistic form in his earlier essays. However, the theoretical coordinates that were to direct Eco's future research were already outlined in his proto-semiotic studies. Nor was text a key category in Eco's A Theory of Semiotics (1976a), a collection of the most important semiotic studies he produced in the ten years following the publication of Opera aperta. In fact, the use of the term was limited to the chapter on "The aesthetic text as invention" (Eco 1976a: 261-276). Here, however, we do not find an explicit definition of text, since the emphasis is mostly on the Jakobson-inspired definition of the adjective aesthetic. ${ }^{8}$

When the notion of text (which in the meantime had been put into circulation by linguistic pragmatics and structural narratology) appeared in Eco's writings, it had a composite nature. The notion acquired elements deriving from the different textual theories Eco drew upon: semiotics, philosophy of

\footnotetext{
6 This third meaning, which will result in the formulation of the principle of interpretive cooperation, was later elaborated by Eco (1979a), where he stated: "so-called open texts are only the extreme and most provocative exploitation - for poetic purposes - of a principle which rules both the generation and the interpretation of texts in general" (Eco 1979b: 4-5).

7 "All the studies I conducted between 1963 and 1975 were aimed mostly, though not exclusively, at identifying the semiotic foundations of the experience of 'openness' I had described, without giving its rules, in Opera aperta" (my translation) [“... tutti gli studi che ho condotto dal 1963 al 1975 miravano (se non unicamente almeno in buona parte) a cercare i fondamenti semiotici di quella esperienza di 'apertura' di cui avevo raccontato, ma di cui non avevo dato le regole, in Opera aperta"] (Eco 1979a: 8).

8 This does not necessarily mean that $A$ Theory of Semiotics does not give any indication regarding a theory of the text. Eco simply does not call it so, and one may reasonably re-read the second part of $A$ Theory of Semiotics on the "Theory of Sign Production" from a textual perspective.
} 
language, narratology, pragmatics, literary criticism, etc. In Lector in fabula, the text is primarily "a chain of expressive devices which must be actualized by the receiver” (Eco 1979a: 50). Implicit in this definition is the idea, derived from linguistic studies on the mechanism of presuppositions, that the interpretative outcomes of the text are in some way expected from the start, and that interpreters are required to fill in what is implicit in the text by means of their own inferential activity. The example Eco uses in order to illustrate this point is the following sentence:

John entered the room. "You're back, then!," exclaimed Mary happily. (Eco 1979a: 51) ${ }^{9}$

On the basis of simple language competence, readers infer that John and Mary are in the same room, that (as there are no indications to the contrary) Mary is talking to John, that the latter had previously gone away (as implied by the presuppositional value of "[you] are back"), that his return was unexpected or uncertain as far as Mary is concerned (as can be inferred from the presence of the adverb "then”), and that John's return is to Mary's liking ("happily"). Already at the level of literal meaning, the information explicitly provided by the text is integrated with information that the text only offers as presupposition.

Eco adds other specifications to the linguistic definition of the text as a "presuppositional machine." From his recent narratological experiences, he inherits a dominant interest in narrative texts endowed with specific syntagmatic rules (Metz's "great syntagma of the narrative”). He also adopts a certain way of representing the "vertical layering"10 of texts, understood as structures of superimposed levels. Although Eco does not rule out that his model of textual cooperation may be extended to other types of text, his choice of focusing on narrative artifacts highlights the structured aspect of a rhetorically hyper-codified textual genre, specifically intended to produce certain effects (e.g., the effect of suspense) on its expected receivers. Eco justifies his decision to adopt narrative texts as a test-bed on which to verify the interpretive cooperation hypothesis by stating that "a fictional narrative encompasses most of the problems posited by other types of texts ... Narrative texts - especially fictional ones - are more complicated than are many others and make the task of the semiologist harder. But they also make it more rewarding” (Eco 1979b: 12-13).

The analyses proposed by Eco in The Role of the Reader to illustrate his theory are based on a short story by Alphonse Allais ("Un drame bien parisien")

\footnotetext{
9 Original Italian from Lector in fabula: "[il testo] rappresenta una catena di artifici espressivi che debbono essere attualizzati dal destinatario" (1979a: 50); "Giovanni entrò nella stanza. 'Sei tronato, allora!,' esclamò Maria, raggiante” (1979a: 51).

10 . The Italian expression used by Cavicchioli (1997: 20) is "sfogliatura verticale."
} 
that, apart from being a narrative text, is also fictional ("artificial narratives" according to the terminology Eco borrows from van Dijk [1976]). Consequently, it concerns "individuals and actions belonging to an imaginary or 'possible' world" (Eco 1979b: 12). ${ }^{11}$ Moreover, Allais's experimental narrative is intended to constantly confound the reader's expectations, and it lends itself to a double level of interpretation (naive and critical), thus presenting a distinct self-referential and aesthetic element (as intended by Jakobson [1960]). In other words, Eco's "paradigmatic" text is a highly sophisticated communicative device that keeps strict control on the interpreter's "inferential walks," while leaving the reader a considerable part of the work of constructing meaning (according to the poetics of the open work). An outstanding example of "self-voiding fiction," "Un drame biene parisien" substantiates the hypothesis according to which the interpretive outcomes of a text are already enmeshed into the structure of the text itself. Eco's notion of the Model Reader, which may be defined as the entire range of the interpretive actions the reader is encouraged or allowed to perform by the text, was introduced precisely in order to account for the functioning of this type of text. ${ }^{12}$

11 It is a known fact that the distinctive characteristic of narrative fiction is its capacity to encourage a "willing suspension [of the reader's] disbelief." thanks to which the interpreter will accept the more or less blatant differences between the "supernumerary" part of the possible narrative world and the actual experience of the real world. Clearly, a similar attitude cannot be extended to the reading of natural narratives (i.e., factual accounts), as seems to be suggested by various contemporary theories of the text which erroneously superimpose the notion of narrativity on the notion of fictionality. On the confusion between the narrative/non-narrative and fictional/factual conceptual pairs, see Pisanty and Pellerey (2004: 259-270).

12 The text, according to Eco (1979a), is a mechanism that, in presenting a series of expressions to the reader, encourages him or her to actualize various presuppositions. Usually, a text is structured in such a way as to foreshadow the interpretive actions of its receiver, and encourages the formulation of certain hypotheses instead of others. For this reason, the text is strewn with clues that, like Tom Thumb's breadcrumbs, direct the reader's interpretations along pre-established paths. But how does the text direct the inferential activity of its reader? Whoever writes a text (be it a shopping list or a report on a scientific experiment) has a particular type of ideal reader in mind, a reader who is endowed with certain linguistic and encyclopedic competences, who belongs to a particular historical context and who is used to making certain inferences rather than others. The author structures the text according to the type of reader in mind, aiming to find a balance between what the author thinks should be explicitly stated and the information that can be easily taken for granted since it is expected to already form part of the encyclopedic knowledge of the intended reader. Consequently, the text predicts the ideal reader who will cooperate with it by attributing meaning to the textual clues, and by filling the implicit gaps in the superficial level according to a specific referential encyclopedia. This ideal reader is what Eco calls the Model Reader. 


\section{Text and semiosis}

At a more theoretically abstract level, Eco (1979) draws the foundations of the theory of textual cooperation onto Peirce's semiotic theory, which he defines as the first "second-generation textual theory," despite the fact that it preceded the so-called "first-generation theories" by a few decades. ${ }^{13}$ What the two generations of textual theories have in common is their aversion to the structuralist dogma of immanence with all its corollaries (including the rigid definitions of code and language). The "textual turn" of linguistic and semiotic studies that took place in the 1960s and 1970s was indeed an interpretive one, since it highlighted the pragmatic aspects of communication and signification, starting from the active role played by the reader/listener in the construction of meaning.

However, the two generations of textual theories diverge on one essential point. The first-generation theories, which, according to Eco, include Buyssens (1943), Prieto (1964), and De Mauro (1971), deny the possibility of disambiguating a text independently from the effective situation in which it is delivered and/ or received and, consequently, they negate the legitimacy of any attempt to study language as a structural system that precedes its discursive actualizations. Second-generation theories instead try to achieve "a wise amalgamation between the two possibilities [establishing] points of contact between the study of language as a structured system ... [and the study] of speeches or texts as products of a language which was or is currently spoken" (Eco 1979a: 13, my translation). ${ }^{14}$ Eco's project of "amending” the inflexibility of orthodox

13 If for the second type we speak of "second-generation theories," it is because of the evaluation of their theoretical complexity, their ability to mediate between various fields of investigation, and their attempt at establishing a unified approach. The fact that some secondgeneration attempts preceded some first-generation attempts is only in part a violation of genetic rules. For example, Peircean semiotics is undoubtedly a second-generation theory. However, certain first-generation theories were necessary for the second-generation ones that preceded them to be accomplished. (my translation) [Se si parla, per il secondo tipo, di teorie di 'seconda generazione' è perché se ne valuta la complessità semiotica, la capacità di mediare tra diversi universi d'indagine, il tentativo di stabilire un approccio unificato. Che poi tentativi di seconda generazione abbiano magari preceduto tentativi di prima generazione costituisce solo in parte una violazione delle regole genetiche. Per fare un esempio, la semiotica peiciana è senz'altro una teoria di seconda generazione: ma ci volevano certo le teorie di prima generazione perché quelle di seconda che le avevano precedute si attualizzassero in pieno] (Eco 1979a: 13).

14 Original Italian from Lector in fabula: "[una seconda generazione] che tentava invece una accorta fusione tra le due possibilità e poneva punti di raccordo tra uno studio della lingua come sistema strutturato ... e uno studio dei discorsi e dei testi come prodotti di una lingua già parlata e in ogni caso parlanda" (1979a: 13). 
structuralism, without abandoning the analysis of language (or rather, of the Encyclopedia) and of texts considered as matrices of possible meanings (a project already announced in A Theory of Semiotics) may be included in this second perspective.

Which aspects of Peircean semiotics are considered relevant to a theory of textual cooperation? Chapter Two of Lector in fabula (which corresponds to Chapter Seven in The Role of the Reader - 1979b: 175-199) deals with the exploration of the various facets of Peirce's theory of the sign (or semiosis), and in particular with the notions of Object (Dynamic and Immediate) and Interpretant, on which Eco's notion of Encyclopedia is based. "A sememe is in itself an inchoative text, whereas a text is an expanded sememe" (1979b: 175). In other words, the meaning of a sign resides in the indefinitely expandable sum total of the effects (or Interpretants) the sign produces or may potentially produce in someone, and therefore in the open series of its possible interpretations.

On one hand, this idea (a reformulation of Peirce's "pragmatic maxim") serves to overcome the aporias in the componential analysis of lexemes to replace the dictionary type semantic models with an encyclopedic model centered on the principle of unlimited semiosis, "we can say that among the interpretants of the word |bambinol ['male child'] we do not only find images of children or definitions like 'human, non-adult, male,' but also, for example, the episode of the Massacre of the Innocents" (Eco 1979a: 35). Apart from this, however, Eco sees in the hypothesis that the interpretations of a sign (or of a text) are in some way already condensed or outlined in the sign itself, "the Cardanic joint that can unite the semiotics of a code to the semiotics of texts and speeches" (Eco 1979a: 49). ${ }^{15}$

The almost Talmudic image of a sign/text that encapsulates all its interpretive possibilities is indeed fascinating, but it also opens a vast array of puzzling questions. How can we establish whether a certain reading belongs to the group of interpretations authorized or encouraged by the text? Should we admit that all the effects produced by a text (including the most extravagant) are "in some way" predicted by the structural matrix of

15 The last two citations do not appear in The Role of the Reader, where we find a discussion of Peirce's same passages with other examples (see 1979b: 184). Original Italian from Lector in fabula: "Potremmo dire che tra gli interpretanti della parola |bambinol non vi sono solo immagini di bambini o definizioni tipo 'maschio umano non adulto' ma anche, per esempio, la vicenda della strage degli innocenti” (1979b: 35); "[in Peirce] si disegna il giunto cardanico che può unire una semiotica del codice a una semiotica dei testi e dei discorsi” (1979b: 49). 
the text itself? Can we say that Freud's reading of Oedipus Rex is potentially included in the structural matrix of Sophocles' work? Or should we rather say that it is not incompatible with the literal meaning of the text? By the same token, can we say that Little Red Riding Hood contains potentially and in condensed form Bettelheim's psychoanalytical reading, which maintains that the folktale deals with an adolescent coming into contact with adult sexuality, with the eternal battle of the sexes (so far so good), and - more curiously - with the frustrated male desire for gestation, as testified by the wolf's attempt to ingest the girl (who eventually punishes his absurd aspirations by filling his belly with rocks, an obvious symbol of masculine sterility)? The question may be put in other terms. Leaving aside the problem of how to distinguish "good" and "bad" interpretations, are the psychoanalytic readings offered by Freud and Bettelheim in some way inscribed in the texts' "genetic codes"? And do the texts simply need to meet the right interpreters to be fecundated and brought to light? Or did Freud and Bettelheim simply concoct more or less interesting interpretations that (in the best of cases) were not incompatible with the literal meaning of the texts they were supposedly deciphering?

In fact, it may be very difficult to establish whether and to what extent a certain "inferential walk" is actually foreshadowed or promoted by the text, especially when one expands the length of text under analysis, and when one passes from the reconstruction of the literal meaning of a basic storyline to the reconstruction of the illative consequences and of the hypothetical meaning(s) buried in the text's most intimate folds. Hence the (legitimate) suspicion that Eco's Model Reader might be a hypostatization of the interpretive performance of a certain empirical reader who mistakes his own personal interpretation for something to be found within the text itself. ${ }^{16}$

Curiously, after having outlined his daring theoretical graft, Eco rarely mentions Peirce in the following chapters of Lector in fabula, if not en passant with regards to the concepts of frame and abduction. The influence of pragmatism is certainly felt throughout the book, especially in the parts on the cognitive operations performed by the Model Reader "in extension" (i.e., the inferences formulated by the Model Reader in order to reconstruct the relationship between the course of events described in the text and its knowledge of the real world). However, it seems that in Lector in fabula the structuralist approach remains predominant, albeit "contaminated" by the unsettling presence of a Reader.

16 Rastier (2003) made this objection to Eco, and he was, by no means, the first one to do so. 
As he introduces the figure of the Model Reader, Eco hastens to underline that this is an abstract role having nothing to do with the empirical reader. In this sense, the Model Reader seems to be very closely related to the énonciataire $^{17}$ referred to by structuralist linguistics: a purely syntactic role inscribed in linguistic structures. However, Eco's theoretical graft creates unforeseen complications, since the role of the Reader resists all attempts to be confined within pre-established boundaries and tends to disarrange the categories that try to capture its essence. In the same manner as other "Readers," which abounded in literary theory in those years ${ }^{18}$ (such as Iser's 1974 implicit reader, which is closest to Eco's Model Reader), the notion of Model Reader contains some grey areas that are worthy of further investigation. The point is that it is not always clear where a purely textual strategy ends and where an interpretive (cognitive) process, ascribable to the initiative of an empirical reader, begins.

\section{The Model Reader as an interpretive strategy}

If we were to identify the Model Reader exclusively with the linguistic marks that inscribe the receiver in the text (the marked "you"), the problem would not exist since the Reader would still be tightly anchored to the enunciative structures (only, in this case we wouldn't need Peirce in our theory). If, however, apart from the enunciative marks that place it within the discourse, the Reader also includes "extensional" functions such as the inferential walks that saturate the text's blank spaces, thus allowing the text to come to life and acquire meaning, then it would

17 Énonciateur and énonciataire are communicative roles inscribed within the text. They do not correspond to the empirical figures involved in the communicative interaction (i.e., author and reader), but are their simulacra represented in the discourse. According to Paolo Fabbri,

Enunciation is the particular means by which intersubjectivity (sender-receiver ...) is inscribed within the discourse itself. Thanks to the mechanism of enunciation, I can say, referring to myself, "You will never understand these things"; in this case I am referring to myself as "you." But I can also refer to a group of listeners as "my kind audience" and refer to myself as "the speaker." in this way using the third person in both cases. The basic idea of enunciation is that in different types of semiotic texts - in music, art, literature, etc. - we find images of interaction which are inscribed within the text itself by means of various processes of enunciation. (Fabbri 2003 [1998]: 54).

18 For a discussion of the various Readers (implicit, ideal, virtual, informed, etc.), see Pisanty and Pellerey (2004: Ch. 4). 
be more difficult to determine the extent to which these functions (or at least their inchoative phase) may be extrapolated from the text, or whether they are dependent on knowledge and cognitive mechanisms that lie outside the text.

In Peircean terms, we can say that the Reader is encouraged to take its inferential walks whenever the text presents an "empty space" (a semantic gap) that needs to be filled. The identification of an empty space is the "surprising fact" that induces the Reader to move out of the text in order to find the premise of an abduction which, if confirmed, would make the fact less surprising, and thus eliminate "the irritation of doubt." For example, when reading "la sventurata rispose" ["the unfortunate woman replied"], all empirical readers of Manzoni's I promessi sposi are encouraged to fill in the spaces that the narrative text intentionally leaves blank: why is the reply of the Nun of Monza to the perfidious Egidio, a harbinger of misfortune? What narrative developments are foreshadowed in her reply? No matter how diverse and idiosyncratic the interpretations provided by specific empirical readers may be, those readers who identify with Manzoni's Model Reader are expected to (at least) understand that they are dealing with an intentionally reticent passage that needs to be filled in inferentially.

Let us assume for a moment that the Model Reader is to be identified not with any specific answer that may be selected to explain the surprising fact in question ("Manzoni's mention of the Nun's reply to Egidio allows us to infer that . .."), but rather in the formulation of the question posed by the text ("Manzoni's mention of the Nun's reply allows us to infer that there is something to be inferred"). Nonetheless, the textual fact that solicits an explanation is never surprising in itself: in order for it to be perceived as a surprising fact, "la sventurata rispose" has to be measured up against a system of expectations that allow the reader to evaluate the degree of its unexpectedness and narrative deviance. It is necessary to be aware of the historical context in which Manzoni's characters interact in order for the Reader to notice this textual blank. In a hypothetical cultural context in which members of monastic communities were free to give vent to their sexual impulses without any type of restriction, the Nun's reply to Egidio would not produce the same degree of interpretive tension that is created when the Reader has an adequate knowledge of the rules on sexual ethics taken for granted by Manzoni in his novel. It follows that the very identification of a text's empty spaces requires, on the Reader's part, an inferential activity triggered by the encounter between the text and the encyclopedic information that lies outside of it. The Model Reader assumes encyclopedic features that go beyond the purely textual dimension, it is deeply rooted in a specific cultural context. Although empirical readers may belong to different contexts (as in the case of contemporary readers confronted with Manzoni's novel), in order to take on the role of the Reader they are required to piece together the Encyclopedia assumed by the text as its necessary background knowledge. Therefore, the Model Reader, which 
is at the root of every possible interpretation of a text, is in itself the product of an abductive line of reasoning, sparked by the encounter between the text and its empirical readers. Which segment of the collective Encyclopedia must I refer to in order to interpret a specific text? What type of inferences am I allowed to (or supposed to) make on the basis of the relevant Encyclopedia? Such questions need to be answered (or at least posed) before an empirical reader may even begin to wonder about the format and identity of a text's Model Reader.

Moreover, the Model Reader seems to be more than a set of blank spaces scattered throughout the text that every empirical reader is free to fill in as he or she pleases. It is not enough to identify the notion of the Model Reader with a series of empty spaces or as textual prompts that kindle the formulation of hypotheses (whichever they may be). Manzoni's Reader is required to form a more precise idea about the consequences of the reply given by the Nun of Monza. It is clear that the Nun's reply anticipates some sort of love encounter between Gertrude and Egidio, with all the social consequences it implies. To miss the erotic significance of the situation would mean to stray from the interpretive path suggested by the text, thus departing from the role of the Model Reader. Obviously, every empirical reader may create his or her own mental representations of the meeting between Gertrude and Egidio, supplying it with more or less specific and salacious details, since the text still contains a certain level of indefiniteness which may be filled only by idiosyncratic empirical interpretations. However, it is just as obvious that a game of canasta is not included in the range of scenarios implicitly foreshadowed by the unfortunate woman's reply.

There seems to be something in the text that directs the readers' interpretive activity by promoting certain preferential reading paths to the exclusion of others. Consequently, the borders between text and extra-text become less clear and the Model Reader is caught between the text and its readers, with one foot in the textual structures and the other in the cognitive and cultural acts that are necessary in order to trace these structures or to interact with them.

Bearing in mind that, at least in the case of verbal texts, the act of conferring meaning takes place over a period of time, as each reader interacts with the linear expression of the text, the Model Reader coincides with the orderly sequence of interpretive acts suggested by the text, i.e., with the interpretive strategy that the text seems to encourage. It should be noted that, in game theory, strategy is defined as the set of choices made by a player in the different situations that arise during a game. In this sense, the Model Reader coincides with the set of interpretive options authorized/suggested by the text to the interpreter at every junction (or disjunction) of probabilities that characterizes the plot. What do you think might happen next? 
Why do you think she (the character) said/did this? What does the text tell you about this or that aspect of human life? ... Often, the Reader is offered a variety of different options, and yet the choices made by empirical readers take place within a range of options permitted by the text.

The center of attention therefore shifts from the text, taken as a structure that encloses the traces of its own predicted receiver, to the text/reader pair that is inextricably interwoven in the production of meaning. The object of semiotics is no longer the text as such, but the interpreted and interpretable text. In this sense, it may be interesting to figure out how a text is interpreted by somebody (an empirical reader), move after move, in order to trace what - within the text could have brought about that particular interpretive outcome, rather than all of the other possible ones.

\section{The limits of interpretation}

In The Limits of Interpretation (1990), Eco does not choose the text itself as the object of his analysis, but rather the interpretive act involving the text/reader pair. This choice implies the adoption of a resolutely Peircean perspective, according to which the meaning of a text resides in the effects produced, or which may be produced, by the text on somebody's mind (and body, and behavior). Eco seems to suggest that in order to understand how a text works, one must start from the reading experience it generates or is capable of generating, both in the analyst (who will consequently have to renounce the claim of seeking to capture the innermost structure of the text independently from his or her own interpretive actions) and in other selected interpreters, whose textually-recorded readings (in the form of critical comments, rewritings and behavior following the reading of the text) are included in the semiotic investigation.

This shift carries the risk of an excessively drastic move towards the reader, stating - as some deconstructionist critics have indeed said - that the meaning of a text is found exclusively in the possible readings of the text itself. Eco refutes the notion of the interpreter's unlimited freedom and defends the rights of the text against the disproportionate claims of the deconstructionist reader. He states that each partner in the interpretive act has a particular role to play in the generation of meaning.

In reply to those who identify the reader as the only producer and judge of the meaning of a text, Eco again takes up and develops the opposition between interpretation and use of a text, which he already outlined in 
The Role of the Reader. ${ }^{19}$ The text does not allow itself to be interpreted in every conceivable way, but it stands as a parameter of its possible interpretations. This means that every reading must be compared with the information explicitly provided by the text before being admitted into the group of acceptable interpretations of the text itself. It is true that in certain cases (those that Eco 1962 called "open works") the text gives its reader ample leeway for interpretive movement. However, even in the most extreme cases, the text always remains in the background to construct the universe of its legitimate interpretations, and the autonomy given to the reader resembles a system of probation rather than full freedom of movement. Empirical readers are obviously free to do as they like, and ignore all the clues the text provides in order to show how it "expects" to be read (or at least how it tolerates being read). However in this case the readers would not be involved in an act of interpretation of the text since they would be substituting interpretive cooperation with unrestrained and uncontrolled use.

Many of Eco's studies in the 1980s deal with situations in which the limits of interpretation are overstepped, leading at times to unexpectedly fruitful consequences, ${ }^{20}$ at others to devastating results (the narrative outcome of these studies is Foucault's Pendulum [1988b], the most "interpretive" of Eco's novels). However, the question about which criteria enable the distinction between interpretation and textual use remains open. Given that meaning is

19 In the context of this book, by interpretation is meant the semantic actualization the text as strategy wants to make through the cooperation of its Model Reader ... One may therefore claim that a text which, through its own structures, manifests the schizoid personality of its author or the latter's Oedipus complex, is not a text which requires the cooperation of an ideal reader to disclose these unconscious tendencies. Pointing out these tendencies does not pertain to the process of textual cooperation ... Consequently, such psychological, psychiatric or psychoanalytic investigations, which are important and useful and which would pertain to a utilitarian use of the text for informative reasons, would constitute a later phase with respect to its semantic actualization. (my translation) [Per interpretazione si intende (nell'ambito di questo libro) la attualizzazione semantica di quanto il testo quale strategia vuole dire attraverso la cooperazione del proprio Lettore Modello ... Si potrebbe allora sostenere che un testo che, attraverso le proprie strutture manifesta la personalità schizoide del proprio autore, o il fatto che egli sia ossessionato da un complesso edipico, non è un testo che chiede la cooperazione di un lettore ideale per rendere palese queste tendenze inconscie. Rilevare queste tendenze non pertiene al processo di cooperazione testuale ... Pertanto tali indagini psicologiche, psichiatriche o psicoanalitiche, importanti e fruttuose, apparterrebbero all'utilizzazione del testo a fini documentari e si porrebbero a una fase successiva alla sua attualizzazione semantica.] (Eco 1979a: 179)

20 In Serendipities (1998a), Eco mentions historical events in which an error or a false interpretation led to discoveries of varying importance. A typical example in this sense is the case of Christopher Columbus's "discovery” of America. 
always the result of an encounter between the text and the reader, and that each reader draws differently from the text to build his or her own image of the Model Reader, how can we say that a particular reading (and consequently a particular image of the Model Reader) is better than another? A solution indicated by Eco, inspired by the Peircean-Popperian principle of the falsification of scientific hypotheses, is that, despite the impossibility of definitely establishing which the best interpretations of a particular text are, there are criteria that help us decide that certain readings are definitely worse than others. If, for example, somebody were to say that in Shakespeare's Hamlet, Hamlet marries Ophelia, one could easily dismiss this reading as a misleading use of the text. There is something within the text that makes it resist being twisted for certain uses.

\section{Three intentions}

In order to clarify the terms of the dispute with the deconstructionists, Eco (1990: 50-51) distinguishes between three types of intention:

1. the intentio auctoris: what the empirical author intends to say;

2. the intentio operis: what the text wants to say with reference to its underlying signification system and by virtue of its textual coherence; ${ }^{21}$

3. the intentio lectoris: what the readers make the text say with reference to their own system of expectations, their wishes, drives, beliefs, and so on.

Neither Eco nor the deconstructionists admit that interpretation may be linked to the intentio auctoris. However, whereas Eco maintains that interpretation is always the result of a synthetic oscillation between intentio operis and intentio lectoris (so that the idiosyncratic and potentially indomitable intention of the reader is kept in check by a sometimes complex system of ties and prompts by which the text tries to control its Reader's interpretive activity), the deconstructionists deny that a text may act as a parameter of its possible interpretations. According to them, empirical readers arbitrarily select the level of relevance from which to start in their interrogation of a text, and there are no specific criteria inherent in the text which permit

21 Eco continues to develop his thoughts about the intentions of the text in his later works, such as those dedicated to the problem of translation. In the Italian edition of Dire quasi la stessa cosa [Saying Almost the Same Thing] (2003a), intentio operis is defined as "the effect desired by the text" [l'effetto che il testo intende raggiungere"] (2003a: 149, my translation). A similar, but less precise argument can be found in Mouse or Rat? (2003b: 71), which is a partial translation of 2003a. 
a distinction between acceptable and unacceptable readings. Any reading will always be a misreading, since it is necessarily partial and incomplete. In other words, as Eco (1992a: 24) teasingly put it borrowing a phrase from Todorov (who quoted from Lichtenberg à propos of Boheme), "a text is only a picnic where the author brings the words and the readers bring the sense."

Between a quasi-irrelevant intentio auctoris and a potentially unbridled intentio lectoris, Eco postulates the presence of a channeling intentio operis, a system of textual guard-rails ${ }^{22}$ that restrain the meanings that may be reasonably attributed to the text itself. The problem is how to define this immanent communicative intention, once it has been definitively unhooked from the communicative intentions of the empirical author. How can a bunch of words "want to say" anything at all? Is it really possible to think of the text as an agent (somebody who wants something), or are we just in the presence of a metaphor that has been taken literally? One can't help noticing that Eco in The Limits of Interpretation does not give a comprehensive answer to these questions, but only some scattered reflections and examples. Among them, one of Eco's recurrent points is the defense of the text's literal meaning. Whatever the secondary and illative meanings attributed by the reader to the text, these meanings cannot contradict the text's most immediate and incontrovertible denotations. Before dwelling on the possible anthropological, ideological, psychological, and other meanings of, for instance, the story of Cinderella, one has to understand that the protagonist has a stepmother, that she loses a shoe and that she finally marries a prince.

When required to reply to those who make claims for the total emancipation of interpretation from the limitations imposed by the text (and the context), Eco does not insist on giving a "positive" definition of what constitutes the intentions of a text. He passes from the wider meaning of intentio operis as a structural matrix to the narrower meaning of intentio operis as a system of restrictions. From this perspective, the intention of a text (as enigmatic as it may be) is manifested negatively whenever a particular reading collides with the literal meaning which may be drawn from the text. Reduced to its literal meaning (that is, to the complete set of lexically bound inferences that the text allows the reader to make), the text is the parameter that enables us to consider certain hypotheses as blatantly false. Whatever the deep (anthropological, religious, symbolic, etc.) isotopes attributable to the story of Cinderella or Little Red Riding Hood, the folktales' literal meanings and fabulae may not be contradicted.

22 The metaphor of the guard-rails that are necessary in order to limit the directions that readings of a text can take has been adopted from Derrida (1967). 
For the scope of semiotic analysis, such a "minimalist" version of the intentio operis may be very useful as it sheds light on the variety of possible ways in which different interpreters "make sense" of texts by filtering them through their own cognitive and encyclopedic structures. While considering a text as the parameter of its possible interpretations, the analyst may choose to examine and compare an array of different interpretive styles or "sense-making" strategies that have been adopted with regard to that specific text. ${ }^{23}$ "Deviant" reading strategies are particularly valuable to the semiologist inasmuch as they reveal, by contrast, the cognitive mechanisms that underlie textual cooperation in its more standard forms. The focus hence shifts from the text as an interpretable object to the interpretive strategies it is able to solicit.

However, we have still not solved the problem of how to define the intentio operis. Saying that the text expresses its intentions negatively does not necessarily imply that there is no structural matrix capable of generating all possible (legitimate) interpretations. It only means that we cannot get to know them unless we bang against them (that is, unless our hypotheses are falsified by something that gets in the way of our interpretive habits). This may be good enough for a single analysis, but it is still insufficient for a theory that aims to explain how human beings saturate the world with meaning through the interpretation of texts. What is lost in this restricted view of the text is the idea of the latter as a presuppositional machine that is able to encourage certain inferences, and not just to discourage others.

In an attempt to get out of this tight corner, we could try the experiment of projecting the three intentiones onto the vertices of Peirce's triangle. The intentio auctoris would correspond to the Dynamic Object ("really efficient but not effectively present," and therefore knowable only through the signs that represent it), the intentio lectoris to the Interpretant (the effect the text has on the interpreter's mind and ensuing behavior), the intentio operis with the Immediate Object ("the Object as represented in the sign," i.e., the communicative intention as it is represented by the text), while the expressive manifestation of the text would coincide with Peirce's Representamen.

The intentio auctoris and the intentio lectoris are psychological events, unknowable in themselves unless they are displayed as signs, and yet quite easy to conceive of as "the cognitive activity that goes on in the author's

23 Examples of this type of analyses may be found in Eco's work on hermetic thought, Chapter Two in I limiti del interpretazione, called "Aspetti della semiosi ermetica" [Aspects of Hermetic Semiosis](1990), which is not translated in the English version of The Limits of Interpretation. Also see the collection of studies on the esoteric interpretations of Dante (Pozzato 1989), the description of the so-called "Bakespeare controversy" (Blasi 1990) and in my examination of the interpretive strategies used by Holocaust deniers (Pisanty 1998). 


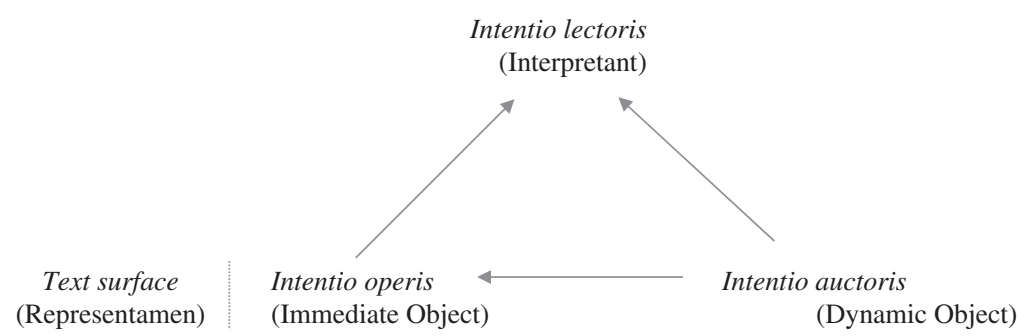

Figure 1: The three intentiones of interpretation as vertices of the Peircean triangle.

and in the reader's minds." The intentio operis acts as an interface between the two: on the one hand it is determined by the intentio auctoris (which, like the Dynamic Object, is the first mover of semiosis) and carries traces of it, and on the other it kindles an indefinite number of effects in empirical readers.

It is very difficult to define the precise semiotic nature of this linking element (as it is difficult to define Peirce's Immediate Object). On the author's side, the intentio operis is a necessarily selective representation of an indefinite continuum of mental events that are channeled within the author's intention to produce certain cognitive effects on somebody through a communicative strategy (the Model Author, in fact). On the reader's side, the intentio operis is the matrix that generates all the possible interpretations of the textual Representamen (the Model Reader, possibly?), as well as the indefinitely extendable sum total of the interpretations produced by the text itself, according to the hermeneutic principle, often quoted by Eco, according to which the meaning of a text gradually becomes "encrusted" with the culturally attested interpretations that have stemmed from it. ${ }^{24}$ It follows that the intentio operis is at the same time the cause and the sum total of the effects of a text. Every empirical interpretation stemming from the text generates some of the outcomes potentially contained within the text, without ever exhausting or capturing the deep structure of the intentio operis once and for all.

We have seen how in Eco the intentio operis may be understood as a seminal possibility that virtually includes all its possible emanations (all its empirical interpretations). But, in order for the possibilities of meaning already foreshadowed in the text's "genetic heritage" to be actualized and come to life, it is necessary for them to be "fertilized," to keep to the

24 See Gadamer (1960). This hermeneutic principle is compatible with the pragmatic maxim, which states that the meaning of a concept corresponds to the total of its possible interpretants or cognitive effects. 
metaphor, by the empirical readers who crossbreed their experience with the textual clues they recognize in the text, thus generating new interpretations. After which, through some sort of Lamarckian heredity of acquired characters, the interpretations produced by the empirical readers (if put at the disposal of the cultural community) are absorbed into the intentio operis itself, thus offering themselves to new fertilizations.

\section{Conclusion}

At this point we might ask ourselves whether in this embrace between text and reader, the author has a role to play or if, once the intentio auctoris has been translated into intentio operis, he simply plays the gooseberry, so to speak. In other words, we must understand whether, other than being the terminus a quo of the semiosic act, the intentio auctoris may also be understood as the terminus ad quem of the interpretive process.

The irrelevance of the intentio auctoris has almost become a cliché in contemporary theories of the text. On this point, Eco's official position does not seem to diverge significantly from that of the reader-response critics, the deconstructionists, the New Critics, the formalists or the structuralists. "What the author really wants to say" is considered by many as an irrelevant issue. Indeed, if the author manages to express his intentions in the text, in the form of a recognizable communicative strategy, then there is no need to peek into his black-box to know what they are. If, on the other hand, he does not manage to express his intentions, then they are irredeemably lost (and bad luck to him).

The (counterintuitive) semiotic idea that the interpretation of a text must be completely free from the attempt to reconstruct its intentio auctoris derives from the fact that for a long time the literary text (1. linguistic, 2. narrative, 3. fictional, 4. prevalently poetic) has been used as a test-bed for the fine-tuning of the concepts and the tools used for the analysis of the semiotics of the text. Allowing the readers to not question the empirical author's real intentions is part of the literary game, as is encouraging them to make use of a wide margin of interpretive manouevres, keeping the criterion of textual coherence as the only parameter of discrimination between interpretation and use. However, it does not necessarily follow that this same interpretive strategy holds for other types of textual/interpretive games.

It is quite obvious that when somebody says something in everyday communication, we are usually interested to find out what this person really wants to tell us. Even if the locutor expresses himself badly and his utterance 
is ambiguous, most receivers are willing to make use of the principle of interpretative charity, as Davidson (1984 [1973]) calls it, in order to reconstruct the most probable intentio auctoris, starting from what they know of the locutor's biography, his expressive style, cultural competences, ideological beliefs, and so on. The fact that misunderstanding is always just around the corner, and that the author's communicative intention is not directly accessible to the interpreter does not mean that the latter is not interested in knowing it. Although it is not "immediately present," the Dynamic Object always looms in the horizon as that "something" towards which interpretation tends. In fact, in most daily communicative interaction, as well as in many other forms of social interaction (in historical, political, legal, journalistic discourse, for instance), the interpreter's main objective is to identify the intentio auctoris starting from the perceptible clues which are present in the form of intentio operis. In some cases, such as confessions, intimate conversation or psychoanalytic exchanges, the rules of the game actually require the interpreter to delve into the deepest layers of the intentio auctoris, in order to bring to light what the intentio operis is possibly concealing.

Moreover, one might also argue that, despite Eco's own assertions, his definition of interpretive semiotics cannot completely do without the intentio auctoris even when dealing with literary texts, i.e., with the kind of textual interaction that, more than any other, plays down the author's role (as opposed to the text's and the reader's) in the process of sense-making. In The Role of the Reader, both the empirical reader and author are cast out from the field of semiotics, ${ }^{25}$ to be replaced by their textual simulacra, specifically by the Model Reader and Model Author. The latter is a discursive strategy, a voice, a style, at any rate something internal to the text. But in Eco's model (1979b: 14) the empirical author is not completely absorbed into the intentio operis as Model Author. There remains an extra-textual residue defined by Eco as "circumstances of utterance" which include "historical period, cultural profile of the speaker, type of linguistic act and so on."26

25 "[I reaffirm that] textual cooperation is a phenomenon that occurs between two discursive strategies, not between two individuals" ["La cooperazione testuale è fenomeno che si realizza ... tra due strategie discorsive, non tra due soggetti individuali”] (Eco 1979a: 63).

26 It is clear that in oral communication before a receiver disambiguates a phrase, he assesses the circumstances in which the utterance was made, the speaker's tone, the information previously gathered on him, etc., in order to understand what plausibly were the communicative intentions of the speaker and, as a consequence, the interpretive attitude to take with respect to the utterance. However, when the text is written, the spatio-temporal distance that separates the reader from the author forces the former to accomplish a series of philological duties, since "these external circumstances are detected ... to be transformed into pieces of 
The decision to include the circumstances of utterance and the type of linguistic act in the schema of levels of textual cooperation shows that for Eco the figure of the empirical author is not completely eliminated from the act of textual cooperation. Even when she is interpreting a literary text, the reader conceived by Eco cannot avoid asking herself "what is this person trying to tell me?" (or "what does she want from me?"). To answer this question, she must choose, from all the possible meanings of each one of the words forming the text, those which plausibly the author (as a spatio-temporally localized individual with whose communicative habits the interpreter is more or less familiar) had in mind. Consequently, to use Eco's example, when faced with Wordsworth's verse "a poet could not but be gay" from the poem I wandered lonely as a cloud, the reader is expected to understand that in Wordsworth's time the term "'gay' had no sexual connotation” (Eco 1992a: 68).

One may object that, in respecting the philological dimension of the text, "these external circumstances are detected ... to be transformed into pieces of encyclopedic knowledge (contextual and circumstantial selections, frames, and any other type of overcoding)" (Eco 1979b: 17). Binding poetic interpretation exclusively to the author's presumed psychological intention would indeed be a sterile and lame strategy on the reader's part. And yet, although the intentio auctoris is in itself impenetrable and, at least in the case of the interpretation of a poetical text as we understand it today, largely negligible, its influence on the interpretive process is never completely eliminated.

The very decision to interpret a text as a fictional rather than a factual narrative (that is, to grasp its illocutory force) is the result of a guessing game concerning the communicative intentions of the author. The fact that these intentions are usually made evident from the generic clues which are manifested in the text and the paratext does not prove that the intentio auctoris is irrelevant. It is sufficient to imagine a situation in which the identification of genre is hindered in some way (as in Orson Welles's broadcast) to understand how, in the absence of definite textual clues, readers are induced to guess the author's possible communicative intentions and are willing to correct their own initial hypotheses if the author intervenes to clarify his intentions. Once the humble rights of this shadow of an empirical author are guaranteed, the reader may take the interpretive paths she or he fancies. If, on the contrary, the bonds of the intentio auctoris were to be totally removed, this would result in the total

encyclopedic knowledge (contextual and circumstantial selections, frames, and any other type of overcoding)" (Eco 1979b: 17). 
emancipation of the reader theorized by certain deconstructionists and the consequent unconditional opening of the text.

In brief, the meaning, or rather meanings of a text derive from the tensive and sometimes variable interaction between the three intentions, none of which may be completely put aside to the advantage of the other two. The (textually anchored) interpretive strategy of the Model Reader establishes limitations to the empirical interpretations, according to the "rules of the game" established and presupposed by every textual genre. There are types of interpretive investigations that emphasize the importance of the author's intentions and prescribe a rigorous philological method which limits the reader's interpretive excursions. Other kinds of interpretive activity (such as literary criticism) reduce the importance attributed to the author's intentions and concede a considerable freedom of movement to the reader. Building a semiotic theory on an unwarranted generalization (the idea that all interpretive cooperation follows the steps of artistic fruition) has possibly caused many of the aporias discussed in this paper. And yet, if we accept that a theory's job is to raise puzzling questions more than to provide definitive answers, then the strength of Eco's interpretive semiotics resides precisely in the loose ends it leaves us with.

\section{References}

Blasi, Giulio. 1990. Bakespeare: Paradoxical operations on the concept of author. Versus 57. 57-94.

Buyssens, Eric. 1943. Les langages et le discours. Brussels: Officine de la publicité.

Cavicchioli, Sandra. 1997. Le sirene. Analisi semiotiche intorno a un racconto di Tomasi di Lampedusa. Bologna: Clueb.

Davidson, Donald. 1984 [1973]. Radical interpretation. In Inquiries into truth and interpretation, 125-139. Oxford, UK: Oxford University Press.

De Mauro, Tullio. 1971. Senso e significato. Bari: Adriatica.

Derrida, Jacques. 1967. De la grammatologie. Paris: Minuit.

Dijk van, Teun. 1976. Philosophy of action and theory of narrative. Poetics 5. 287-322.

Eco, Umberto. See Selected Bibliography in this volume.

Fabbri, Paolo. 2003 [1998]. La svolta semiotica. Rome \& Bari: Laterza.

Gadamer, Hans Georg. 1960. Warheit und Method. Tübingen: Mohr.

Iser, Wolfgang. 1974. The implied reader. Baltimore, MD: Johns Hopkins University Press.

Jakobson, Roman. 1960. Closing statements: Linguistics and poetics. In Thomas Sebeok (ed.),

Style in language, 350-377. Cambridge, MA: MIT Press.

Nanni, Luciano. 1987. Contra dogmaticos. Bologna: Cappelli.

Pareyson, Luigi. 1954. Estetica. Teoria della formatività. Milan: Bompiani. 
Peirce, Charles S. 1931-1966. The collected papers of Charles S. Peirce, 8 vols., C. Hartshorne, P. Weiss \& A. W. Burks (eds.). Cambridge: Harvard University Press. [Reference to Peirce's papers will be designated $C P$ followed by volume and paragraph number.]

Pisanty, Valentina. 1998. L'irritante questione delle camere a gas: logica del negazionismo, Milan: Bompiani.

Pisanty, Valentina \& Roberto Pellerey. 2004. Semiotica e interpretazione. Milan: Bompiani. Pozzato, Maria Pia (ed.). 1989. L'idea deforme. Interpretazioni esoteriche di Dante. Milan: Bompiani.

Prieto, Luis. 1964. Principes de noologie. The Hague: Mouton.

Rastier, François. 2003. Arts et sciences du texte. Paris: Presses Universitaires de France. 